Jurnal Indonesia Sosial Teknologi: p-ISSN: 2723 - 6609

e-ISSN: 2745-5254

Vol. 2, No. 1, Januari 2021

\title{
TINJAUAN PENERAPAN EKONOMI HIJAU DALAM PARIWISATA DI PROVINSI BALI REVIEW OF THE APPLICATION OF GREEN ECONOMY IN TOURISM IN BALI PROVINCE
}

\section{Anom Priantoko, Elva Fairuz Anbia, Grace Margaretha Retno Wulan dan Nelson Panggabean}

Politeknik Keuangan Negara STAN

Email: Prian.anomo@gmail.com, elvafairuz@gmail.com,grcemrgreth@gmail.com, nelsonpanggabean123@gmail.com

\begin{abstract}
Indonesia as a developing country has a fairly high and stable economic growth. This good economic growth is supported by income from various regions, one of which is Bali Province. The province of Bali has a GDP which is dominated by the tourism sector, as it is widely known by the Indonesian people and the global community. Tourism in Bali, which is so famous, uses a lot of natural resources, both from natural products and the environment itself. Although the contribution made by the tourism sector to Bali Province is quite large, the negative impact of the utilization of natural resources in this sector is quite concerning. The amount of natural damage in the coastal areas of Bali and the increasing effect of greenhouse gases due to the density of population activities has motivated the Provincial Government of Bali to launch the Bali Program Clean and Green. This program was launched in 2015 and is expected to give awareness to the public to always maintain the sustainability of the environment and as a means of realizing a green economy in Bali Province. This study aims to determine how the Bali Clean and Green program is implemented and to determine the barriers to implementing the program in relation to the forming factors of a green economy. The research method we use is a review of various rules and regulations related to the topic and descriptive analysis methods.
\end{abstract}

Keyword: green economy; natural resources; sustainable tourism.

\begin{abstract}
Abstrak
Indonesia sebagai salah satu negara berkembang memiliki pertumbuhan ekonomi yang cukup tinggi dan stabil. Pertumbuhan ekonomi yang baik itu didukung oleh pendapatan dari berbagai daerah, salah satunya adalah Provinsi Bali. Provinsi Bali memiliki PDRB yang didominasi oleh sektor pariwisata, sebagaimana telah dikenal luas oleh masyarakat Indonesia maupun masyarakat global. Pariwisata Bali yang begitu terkenal banyak memanfaatkan sumber daya alam, baik dari hasil alamnya maupun lingkungan itu sendiri. Meskipun kontribusi yang diberikan oleh sektor pariwisata pada Provinsi Bali ini cukup besar, dampak negatif dari pemanfaatan sumber daya alam pada sektor ini cukup memprihatinkan. Banyaknya kerusakan alam di daerah pantai Bali dan meningkatnya efek gas rumah kaca karena padatnya aktivitas penduduk membuat pihak Pemerintah Provinsi Bali tergerak untuk
\end{abstract}


meluncurkan Program Bali Clean and Green. Program ini diluncurkan pada tahun 2015 dan diharapkan memberi kesadaran pada masyarakat untuk senantiasa menjaga keberlangsungan lingkungan hidup dan sebagai salah satu sarana perwujudan ekonomi hijau di Provinsi Bali. Penelitian ini bertujuan untuk mengetahui bagaimana penerapan program Bali Clean and Green dan mengetahui hambatan penerapan program tersebut dalam kaitannya dengan faktor-faktor pembentuk ekonomi hijau. Metode penelitian yang kami gunakan adalah tinjauan dari berbagai aturan maupun regulasi terkait topik serta metode analisis deskriptif.

Kata kunci: green economy; sumber daya alam; sustainable tourism.

\section{Pendahuluan}

Berdasarkan analisis Location Quotient (LQ) yang dilakukan oleh Bank Indonesia tentang Komponen-komponen Sumbangan Pertumbuhan dan Pergeseran PDRB Bali pada tahun 1998-2005, sumbangan terbesar dalam pembentukan PDRB Bali diberikan oleh sektor perdagangan, hotel, dan restoran (PHR) (Pan et al., 2018). Kontribusi yang diberikan sektor tersebut mencapai 30-31\%. Sebagaimana yang kita ketahui, subsektor hotel dan restoran merupakan penunjang utama industri pariwisata. Selain itu, (Adnyana \& Primasari, 2020) menyatakan bahwa sektor pariwisata di Provinsi Bali berkontribusi sebesar 37,28\% pada PDRB Provinsi Bali. Dari kedua data tersebut, kita tahu bahwa pendapatan Provinsi Bali didominasi oleh sektor pariwisata serta sektor-sektor lain yang menunjang (Yoety, 2008).

Sejalan dengan hal tersebut, berdasarkan laporan Inventarisasi Gas Rumah Kaca dan MPV Kementerian Lingkungan Hidup dan Kehutanan Republik Indonesia, trend Emisi Gas Rumah Kaca pada tahun 1998-2005 cenderung mengalami kenaikan. Emisi Gas Rumah Kaca yang berhubungan erat dengan pariwisata adalah Emisi Gas Rumah Kaca yaitu pada sektor energi dan limbah (Lestari, 2017).

Melihat adanya dampak negatif dari kelangsungan ekonomi di Provinsi Bali, pada tahun 2010 Gubernur Provinsi Bali meluncurkan program Bali Clean and Green. Hal ini dimaksudkan untuk memberikan kesadaran pada masyarakat akan pentingnya isu lingkungan dan ekonomi berkelanjutan (Steni et al., 2010). Ekonomi berkelanjutan yang selaras dengan ekonomi hijau ini dalam teorinya seharusnya diterapkan dengan mempertimbangkan beberapa faktor seperti pertumbuhan ekonomi, perbaikan lingkungan dan keberlanjutan lingkungan, khususnya pada sektor pariwisata (Haryanto, 2014).

Penelitian ini bertujuan untuk mengetahui bagaimana program Bali Clean and Green dan bagaimana pengaruhnya terhadap pertumbuhan ekonomi, terutama dalam sektor pariwisata di Provinsi Bali (Adnyana \& Primasari, 2020). Disini peneliti ingin membuktikan, apakah penerapan Ekonomi Hijau yang telah dilakukan oleh Provinsi Bali sudah memenuhi semua faktor yang telah disebutkan sebelumnya serta menemukan faktor-faktor penghambat dalam penerapan Ekonomi Hijau di Provinsi Bali.

\section{Metode Penelitian}

Metode yang digunakan pada penelitian ini merupakan metode penelitian analisis deskriptif dan tinjauan atas peraturan yang telah dibuat oleh pemerintah terkait ekonomi hijau. Metode ini ditujukan untuk menyajikan gambaran lengkap mengenai 
Anom Priantoko, Elva Fairuz Anbia, Grace Margaretha Retno Wulan dan Nelson Panggabean

praktik ekonomi hijau yang telah dilakukan di Provinsi Bali. Data yang diperoleh merupakan data-data sekunder dari pihak kedua yang kompeten di bidangnya.

Tabel 1:

Persen Pertumbuhan PDRB sektor akomodasi dan penyediaan makan minum (yoy)

Sumber : Laporan Perekonomian Bali Terbitan BI Januari 2016 dan Februari 2019

\begin{tabular}{|c|c|c|c|c|c|c|c|c|c|c|c|c|c|c|c|c|c|c|c|c|c|c|c|c|c|}
\hline \multirow{2}{*}{ Pertumbuhan PDRB $(\%$, yoy $)$} & \multicolumn{4}{|c|}{2015} & \multicolumn{5}{|c|}{2016} & \multicolumn{5}{|c|}{2017} & \multicolumn{5}{|c|}{2018} & \multicolumn{5}{|c|}{2019} & \\
\hline & 1 & II & III & IV & 2015 & I & II & III & IV & 2016 & 1 & II & III & IV & 2017 & 1 & II & IIII & IV & 2018 & 1 & II & III & IV & \\
\hline Penyediaan Akomodasi dan Makan Minum & 7,42 & 6,18 & 6,88 & 4,82 & 6,31 & 5,15 & 6,82 & 6,4 & 7,5 & 6,48 & 9,47 & 9,73 & 10,59 & 6,35 & $\mid 9,03$ & 6,35 & 6,16 & 4,25 & 8,43 & 6,27 & 4,55 & 3,07 & 5,54 & 6,03 & 4,81 \\
\hline
\end{tabular}

Gambar 1:

Proyeksi emisi gas rumah kaca di Pulau Jawa dan Bali

Sumber : Pedoman Teknis Perhitungan Baseline Emisi Gas Rumah Kaca Sektor Berbasis Energi

Bappenas 2014

\begin{tabular}{|c|c|c|c|c|c|c|}
\hline & 2010 & 2012 & 2014 & 2016 & 2018 & 2020 \\
\hline Banten & $3,876,200$ & $4,292,200$ & $4,698,200$ & $5,113,800$ & $5,550,200$ & $6,002,500$ \\
\hline Jawa Barat & $11,887,442$ & $13,559,985$ & $15,232,528$ & $17,243,097$ & $19,591,692$ & $21,940,286$ \\
\hline Jawa Timur & $10,627,383$ & $11,546,809$ & $12,428,283$ & $13,426,207$ & $14,379,066$ & $15,341,371$ \\
\hline $\begin{array}{l}\text { Jawa } \\
\text { Tengah }\end{array}$ & $9,910,000$ & $12,380,000$ & $15,490,000$ & $19,390,000$ & $24,270,000$ & $30,400,000$ \\
\hline Yogyakarta & 231,860 & 270,960 & 317,220 & 371,380 & 434,780 & 509,010 \\
\hline Bali & $2,193,512$ & $2,467,050$ & $2,796,660$ & $3,171,175$ & $3,596,808$ & $4,080,643$ \\
\hline DKI Jakarta & - & - & - & - & - & - \\
\hline $\begin{array}{l}\text { Total } \\
\text { Propinsi }\end{array}$ & $38,726,397$ & $44,517,004$ & $50,962,891$ & $58,715,659$ & $67,822,546$ & $78,273,810$ \\
\hline
\end{tabular}

\section{Hasil dan Pembahasan}

\section{A. Data PDRB dan Data Proyeksi Emisi}

Berdasarkan data Laporan Perekonomian Provinsi Bali yang diperoleh dari Bank Indonesia pada tahun 2019, pertumbuhan ekonomi Provinsi Bali pada triwulan IV 2019 tercatat sebesar 5,51\% (yoy) dan meningkat dibandingkan triwulan III. Namun, kinerja ekonomi Bali pada tahun yang sama tercatat sebesar 5,36\% (yoy), cenderung melambat dibandingkan tahun sebelumnya. Penyebab utama penurunan angka kinerja ini adalah efek penyelenggaran IMF-WB Annual Meeting 2018, sehingga masifnya kegiatan ekonomi pada saat itu mendukung pertumbuhan ekonomi yang tinggi di tahun 2018.

Terkait perkembangan inflasi, Provinsi Bali pada triwulan IV 2019 tercatat memiliki perkembangan inflasi sebesar 2,38\% (yoy), cenderung melandai dibandingkan triwulan III 2019. Sementara itu, realisasi inflasi Provinsi Bali pada tahun 2019 tercatat sebesar 2,38\% (yoy), cenderung melandai dibandingkan dengan inflasi tahun 2018. Jika dilihat dari sisi permintaan, perlambatan tersebut disebabkan oleh melambatnya kinerja ekspor luar negeri dan investasi. Sedangkan di sisi penawaran, perlambatan ini disebabkan oleh tertahannya kinerja lapangan usaha pertanian, konstruksi, perdagangan, dan penyediaan akomodasi makan-minum (Iswara et al., 2019).

Dari Tabel 1 dapat dilihat bahwa Pertumbuhan PDRB sektor akomodasi dan penyediaan makan minum pada Provinsi Bali meningkat setiap tahunnya. Sedangkan Gambar 1 menunjukkan proyeksi emisi gas rumah kaca di Pulau Jawa dan Bali, dengan proyeksi emisi gas rumah kaca di Pulau Bali selalu meningkat setiap dua tahun (data menunjukkan data per dua tahun).

Dengan melihat di atas dimana proyeksi emisi gas rumah kaca dan pertumbuhan ekonomi selalu bertambah tiap tahun, pengadaan Program Bali Clean and Green sudah sangat tepat mengingat banyaknya dampak negatif dari aktivitas ekonomi yang tinggi 
yang mengakibatkan emisi gas rumah kaca makin meningkat. Program ini menjadi solusi untuk tetap menggerakkan roda ekonomi, khususnya bagi sektor pariwisata sambil tetap mengedepankan kelestarian lingkungan (Julianti, Nasirun, \& Wembrayarli, 2018).

\section{B. Pariwisata yang berkelanjutan}

Dalam penerapannya, Program Bali Clean and Green telah didukung oleh banyak pihak, baik pemerintah pusat maupun pemerintah daerah. Salah satu bentuk dukungan pemerintah pusat adalah ditetapkannya Provinsi Bali sebagai Kawasan Nasional Energi bersih oleh kementerian Energi dan Sumber Daya Mineral Republik Indonesia dalam Keputusan Nomor 4421 K/20/MEM/2015. Selain itu, banyaknya juklak maupun pedoman yang diterbitkan oleh pemerintah Provinsi Bali membantu percepatan penerapan ekonomi hijau dalam kawasan tersebut (Asmadi \& Yuda, 2019).

Untuk mencapai iklim pariwisata yang berkelanjutan, banyak hotel di Provinsi Bali yang saat ini berkomitmen untuk menjaga kebersihan dan kenyamanan tempat usahanya (Pramesti, 2019). Bagi pelaku usaha perhotelan, salah satu mewujudkan usaha yang selaras dengan lingkungan adalah dengan mendapatkan sertifikat green hotel. Untuk mendapatkan sertifikat tersebut perlu dilakukan benchmarking pada aspek air, energi, dan limbah, serta sertifikasi atas praktik operasional perusahaan. Tidak hanya bangunan saja yang dinilai, praktik bisnis perusahaan juga ikut dinilai untuk mendapat sertifikat green hotel sehingga hal ini sesuai dengan konsep ekonomi hijau (Larashati, 2017).

Selain itu, dalam masa pandemi COVID-19 pemerintah pusat melalui Kementerian Pariwisata dan Ekonomi Kreatif/Badan Pariwisata Dan Ekonomi Kreatif memberikan solusi untuk menjamin kebersihan dan kenyamanan tempat wisata serta untuk mendongkrak roda ekonomi, khususnya pada sektor pariwisata (Anam, n.d.). Solusi tersebut adalah menerbitakan Sertifikat CHSE (Cleanliness, Health, Safety, and Environmental Sustainability). Tujuan penerbitan sertifikat ini adalah untuk mendukung keberlangsungan ekonomi di tengah pandemi COVID-19. Sertifikat ini diberikan kepada Usaha Pariwisata, Destinasi Pariwisata, dan Produk Pariwisata lainnya untuk memberikan jaminan kepada wisatawan terhadap pelaksanaan Kebersihan, Kesehatan, Keselamatan, dan Kelestarian Lingkungan.

Selain sertifikat yang telah disebutkan, Dinas Pariwisata Kota Denpasar juga menerbitkan Sertifikat Tata Kehidupan Era Baru Sektor Pariwisata bagi tempat wisata di Denpasar untuk mempermudah wisatawan dalam memilih lokasi menginap atau lokasi tempat wisata di Denpasar. Dengan banyaknya dukungan tersebut, Program Bali Clean and Green dapat dijalankan dengan baik demi mencapai lingkungan dan ekonomi yang berkelanjutan di wilayah Provinsi Bali.

\section{Hambatan}

Berdasarkan Rencana Strategis Dinas Lingkungan Hidup Provinsi Bali Tahun 2014 - 2018, terdapat beberapa hambatan penerapan Program Bali Clean and Green, antara lain:

1. terdapat penurunan kualitas air yang disebabkan oleh limpahan limbah maupun sampah yang dibuang ke sungai, danau maupun laut;

2. terdapat penurunan indeks kualitas udara karena banyaknya kendaraan bermotor maupun aktivitas penduduk; 
Anom Priantoko, Elva Fairuz Anbia, Grace Margaretha Retno Wulan dan Nelson Panggabean

3. berkurangnya lahan hijau di area perkotaan karena maraknya alih fungsi lahan;

4. rendahnya tingkat kepedulian masyarakat terhadap keberlangsungan lingkungan hidup;

5. belum memadainya peralatan maupun staf pada laboratorium lingkungan;

6. wilayah pesisir dan laut mengalami kerusakan yang semakin meningkat;

7. terdapat kerusakan pada ekosistem maupun aneka ragam hayati;

8. hukum terkait kelestarian lingkungan hidup yang kurang diawasi dan sanksi atas pelanggaran hukum yang kurang tegas.

Adapun isu-isu strategis berdasarkan analisis lingkungan internal maupun eksternal di Provinsi Bali adalah sebagai berikut.

1. Pencemaran lingkungan;

Pencemaran lingkungan ini meliputi pencemaran udara, air dan tanah.

2. Perusakan lingkungan;

Lingkungan yang rusak termasuk perusakan ekosistem maupun semakin langkanya keanekaragaman hayati di Provinsi Bali.

3. Pelanggaran hukum terkait lingkungan hidup.

\section{Kesimpulan}

Kenaikan PDRB di Provinsi Bali selaras dengan proyeksi emisi gas rumah kaca pada Provinsi Bali. Karena itulah pentingnya pembentukan Program Bali Clean and Green dalam menjaga keberlangsungan lingkungan hidup dan ekonomi yang berkelanjutan. Dalam pelaksanaannya, Program Bali Clean and Green paling berpengaruh pada sektor pariwisata di Provinsi Bali. Dalam pelaksanaannya, program tersebut telah didukung dengan banyaknya aturan maupun sertifikasi yang diterbitkan berbagai pihak untuk memastikan terwujudnya sektor pariwisata yang berkelanjutan. Masyarakat makin sadar betapa pentingnya menjaga keseimbangan dan keberlangsungan alam sekitar. Meski begitu, program Program Bali Clean and Green masih perlu ditingkatkan lagi. Pemerintah daerah dapat memberi penegasan atas aturan yang sudah dibuat selama ini, sehingga apabila ada pihak yang melanggar aturan tersebut mendapat sanksi yang setimpal. 
Tinjauan Penerapan Ekonomi Hijau Dalam Pariwisata di Provinsi Bali Review Of The Application Of Green Economy In Tourism In Bali Province

\section{Bibliography}

Adnyana, I. Made, \& Primasari, Agustiya Hutri. (2020). Tourism as a Mainstay Sector towards a Green Economy in Indonesia (Study: Bali Tourism). AYER JOURNAL, 27(3), 96-111.

Anam, A. Khoirul. (n.d.). BISNIS.

Asmadi, Muhammad, \& Yuda, Kautsar Restu. (2019). "RUMAH TUNEL JAMUR" BUDIDAYA JAMUR MERANG RAMAH LINGKUNGAN OLEH KELOMPOK TANI DI DESA TELUK MEKU KECAMATAN BABALAN KABUPATEN LANGKAT SUMATERA UTARA. PROSIDING SEMINAR NASIONAL INOVASI TEKNOLOGI UNTUK MASYARAKAT, 46.

Haryanto, Joko Tri. (2014). Model pengembangan ekowisata dalam mendukung kemandirian ekonomi daerah studi kasus provinsi DIY. Jurnal Kawistara, 4(3).

Iswara, Ida Bagus Ary Indra, Santika, Putu Praba, Wijaya, I. Nyoman Saputra Wahyu, Suwijati, Ni Made, Rama, Vanny Oktafia Putri, Astawa, I. Ketut, Wendri, I. Gusti Made, Mudana, I. Gede, Jayanegara, I. Nyoman, \& Putra, I. Wayan Wiasthana Ika. (2019). Bali Membangun Bali Volume 2 Nomor 2 Agustus 2019 (Vol. 2). Bappeda Litbang Provinsi Bali.

Julianti, R., Nasirun, M., \& Wembrayarli, W. (2018). PELAKSANAAN PERILAKU HIDUP BERSIH DAN SEHAT (PHBS) DI LINGKUNGAN SEKOLAH. Jurnal Ilmiah Potensia. https://doi.org/10.33369/jip.3.2.76-82

Larashati, Mitra Utami. (2017). Penilaian Prestasi Kerja Pegawai Negeri Sipil (PNS) Pada Badan Pendapatan Daerah (BAPENDA) Kota Padang. Universitas Andalas.

Lestari, Juwita Amanda. (2017). Strategi Adaptasi dan Mitigasi Penurunan Emisi Gas Rumah Kaca (Grk) Sektor Transportasi Dan Sektor Persampahan di Kota Batu. Institut Teknologi Sepuluh Nopember.

Pan, Shu Yuan, Gao, Mengyao, Kim, Hyunook, Shah, Kinjal J., Pei, Si Lu, \& Chiang, Pen Chi. (2018). Advances and challenges in sustainable tourism toward a green economy. Science of the Total Environment, 635, 452-469.

Pramesti, Dinar Sukma. (2019). IMPLEMENTASI KONSEP TRI HITA KARANA PADA AKOMODASI PARIWISATA DI NUSA DUA, BALI (Study Kasus: Melia Bali Villas and Spa Resort). Journey (Journal of Tourismpreneurship, Culinary, Hospitality, Convention and Event Management), 1(1), 207-228.

Steni, Bernadinus, Sartika, Iwi, Gawing, Laurensius, Safitri, Myrna A., Rahman, Rano, \& Purwanto, Semiarto Aji. (2010). REDD di Indonesia: Ke mana akan melangkah. HuMa. 
Anom Priantoko, Elva Fairuz Anbia, Grace Margaretha Retno Wulan dan Nelson Panggabean

Yoety, Oka A. (2008). Ekonomi pariwisata: introduksi, informasi, dan aplikasi. Penerbit Buku Kompas. 